\title{
Consolidation And Profitability In The U.S. Banking Industry
}

\author{
Joseph N. Heiney, Elmhurst College, USA
}

\begin{abstract}
This paper examines the changes in profitability in the U.S. banking industry during the continuing consolidation since Riegle-Neal became fully effective. It presents information on the changes in profitability in the U.S. banking industry to determine whether or not the trends observed in the immediate aftermath of Riegle-Neal have continued.
\end{abstract}

Keywords: Banking, consolidation, profitability

\section{INTRODUCTION}

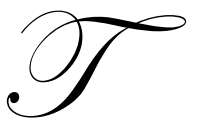

he McFadden Act of 1927 and other legislation restricted the ability of U.S. banks to engage in interstate banking and branching. The Riegle-Neal Banking and Branching Efficiency Act of 1994 removed these restrictions by allowing banks to request regulatory approval for mergers across state lines. Section 44, a) 1) stated that beginning on June 1, 1997 interstate mergers could be approved. Section 44, a) 3) indicated that such mergers could be approved before June 1, 1997 if the home states of each bank involved in the merger approved interstate banking merger transactions with all out of state banks. This was expected to accelerate the trend toward consolidation which was already taking place in the U.S. banking industry.

In previous research Matasar and Heiney (2002) studied the immediate effects of the deregulation instituted by Riegle Neal. They examined the effects of the act on consolidation in the U.S. banking industry in terms of the number of banking institutions, merger and acquisition activity, the number of de novo banks, the number of bank failures, and the number of bank branches. In addition, they studied the impact on asset size distribution, bank profitability, the availability of service and the level of fees, and employment and compensation in the industry.

Since Riegle-Neal was passed in 1994 and became fully effective in 1997, Matasar and Heiney examined data from 1990 to 1998 to capture the initial impact of the act by looking at the period from before the act was passed to immediately after the act became fully effective. They indicated that:

This study of Riegle-Neal may appear somewhat premature or preliminary because of the short period of time since the law was enacted and fully enforceable. Nonetheless the findings herein reveal the direction that changes associated with the law are likely to take and thus serve as a base-line for future analysis.

The snowball of change in the banking community continues to roll and pick up speed even as this book is being written. What is being presented here, therefore, is a still photo of a moment in time, as well as comparison with the past. The future of banking and of financial services in the $21^{\text {st }}$ century is likely to differ considerably from what it was at the end of the $20^{\text {th }}$ century. Hopefully this book offers a foundation for further thought and understanding of the future now being considered. (Matasar and Heiney, 2002, p. viii.)

This paper examines the changes in profitability in the U.S. banking industry during the continuing consolidation since Riegle-Neal became fully effective. It presents information on the changes in profitability in the U.S. banking industry to determine whether or not the trends observed in the immediate aftermath of Riegle-Neal have continued. 


\section{THE CAUSES AND CONSEQUENCES OF CONSOLIDATION IN THE BANKING INDUSTRY}

When Riegle-Neal eliminated the restrictions on interstate banking and branching activity, it was expected that newly available merger and acquisition opportunities across state lines would accelerate the consolidation among U.S. banks already underway. There were concerns regarding the resulting impact on the level of bank services and fees and on employment in the industry. Rose (1997) presents a thorough examination of the possible consequences of the increased consolidation resulting from increased interstate banking.

One reason to expect increased merger activity was the opportunity to take advantage of economies of scale. A merger can be a less costly way to achieve efficient asset size than internal expansion. Calem (1994) indicates that there are economies of scale in the banking industry up to an asset size of $\$ 75$ million. Economies of scale seem to run out for banks with assets between $\$ 75$ and $\$ 300$ million. Beyond $\$ 300$ million in assets, diseconomies of scale seem to set in.

Merger activity may also be a mechanism to replace inefficient management. Calomiris and Karceski (1998) ask, "Is the Bank Merger Wave of the 1990s Efficient?" The economic analysis of government regulation often argues that regulation has the effect of protecting less efficient firms from competition by more efficient firms. Economides, Hubbard, and Palia (1996) present a political economy model in which it is argued that federal branching restrictions were designed to protect smaller, less efficient banks from larger, more efficient banks. Jayaratne and Strahan (1998) also examine the relationship between entry restrictions and efficiency for commercial banks.

It can also be argued that the interstate mergers newly allowed by Riegle-Neal provided an opportunity for banks to reduce risk through geographic diversification. The extent to which geographic diversification reduces risk for an institution depends on the correlation of economic conditions in different areas of the country. If economic conditions are very highly positively correlated across regions of the country, then geographic expansion through interstate banking and branching will not contribute significantly to the objective of risk reduction. Carlino and Sill (2000) find that the correlation coefficients for real per capita personal income across the regions of the U.S. are typically above 0.88 . The far west region is an exception for which correlation coefficients with the other seven regions are between 0.20 and 0.32 . Sherwood-Cali (1990) examines the economic stability of different regions of the country in terms of state industry diversification. She finds that the reduction of volatility due to industry diversification provides the opportunity of risk reduction through geographic expansion of financial institutions.

Smoluk, Andrews, and Voyer (2003) provide a methodology for examining the "potential benefits of risk reduction for financial institutions wishing to grow primarily through a strategy of geographic expansion." (p. 47) They find that "by strategically investing in different regions, a financial institution could reduce its potential earnings risk by over 58 percent while maintaining or improving potential profitability." (p. 48)

\section{CONSOLIDATION IN THE U.S. BANKING INDUSTRY: 1990 - 1998}

Between 1990 and 1998 the number of banking institutions in the U.S. decreased by 3,288 or $26.7 \%$ from 12,303 to 9,015 . The change in the number of banking institutions is determined by the number of mergers and acquisitions, the number of bank failures, and the number of new banks formed. This decrease in the number of banks was primarily due to merger and acquisition activity during this period. From 1990 to 1998 there were 4,944 banking mergers. During this period there were only 70 bank failures. Therefore, mergers and failures would have resulted in a decrease in the number of banks of 5,014. The fact that the number of banking institutions decreased by less than this amount is due to the 1,071 de novo banks which began operation in this period. Furthermore, the effect of the decreasing number of institutions on the availability of service was ameliorated by an increase in the number of bank branches by 13,396 from 49,848 to 63,244. (Matasar and Heiney, 2002)

\section{CONSOLIDATION IN THE U.S. BANKING INDUSTRY SINCE RIEGLE-NEAL: 1998 - 2004}

Table One presents information on the number of commercial banks and the percentage changes in the number of commercial banks from 1993 to 2004. These data are slightly different from those reported in Matasar 
and Heiney (2002) because they come from a different FDIC report, and the data reported above for 1990 to 1998 did not include the District of Columbia. In Table One the number of banking institutions decreased from 11,463 to 8,774 between 1992 and 1998. The number of banking institutions was decreasing at a rate of over $4 \%$ per year during this period. Between 1999 and 2004 the number of banking institutions decreased from 8,580 to 7,630. In percentage terms, this represents a rate of decrease of only about $1.5 \%$ to just over $3 \%$ per year. It appears that the rate of consolidation has slowed since the initial impact of Riegle-Neal.

Table One

Number of Banks and

Percent Change Number of Banks

\begin{tabular}{|c|c|c|}
\hline Year & Number of Banks & $\begin{array}{c}\text { Percent Change } \\
\text { Number of Banks }\end{array}$ \\
\hline 1992 & 11,463 & -4.397 \\
\hline 1993 & 10,959 & -4.626 \\
\hline 1994 & 10,452 & -4.889 \\
\hline 1995 & 9,941 & -4.154 \\
\hline 1996 & 9,528 & -4.041 \\
\hline 1997 & 9,143 & -4.036 \\
\hline 1999 & 8,774 & -2.221 \\
\hline 2000 & 8,580 & -3.089 \\
\hline 2001 & 8,315 & -2.826 \\
\hline 2001 & 8,080 & -2.376 \\
\hline 2004 & 7,888 & -1.496 \\
\hline
\end{tabular}

Source: FDIC, Statistics on Banking

\section{CONSOLIDATION AND PROFITABILITY IN THE U.S. BANKING INDUSTRY: 1996-1998}

Profitability can be measured in a variety of ways. Data from the FDIC, including return on assets (ROA), return on equity(ROE), percent of unprofitable institutions, and percent of institutions with earnings gains, will be used here to examine the relationship between consolidation and profitability. Matasar and Heiney (2002) made the following findings in their study of the initial impact of Reigle-Neal.

\section{Return on Assets}

Nationally, the ROA rose from 1996 to 1999 by $10.08 \%$ despite the increase of $1.60 \%$ in the credit-loss provision to net charge-offs and an increment of $5.17 \%$ in net charge-offs to loans and leases. (p. 29)

\section{Return on Equity}

The national banking industry posted a gain of 6.16\% in the composite ROE from 1996 to 1999. Half the states recorded expanded ROEs among their banks, whereas the other half had ROEs that contracted. (p. 29)

\section{Percent of Unprofitable Institutions}

Most disconcerting was the extremely large increase, $68 \%$, in the number of unprofitable banking institutions during the period 1996-1999. In the final analysis, this was a most telling figure because it clearly demonstrated that the period of banking consolidation had either injured or been unable to save a substantial portion of the industry members experiencing financial difficulties. The anticipated benefits of cross-border mergers and acquisitions are brought into question by this finding. (p. 29) 


\section{Percent of Institutions with Earnings Gains}

The national decline of $-10.82 \%$ in the number of banking institutions with earnings gains augments the findings related to the growth in the unprofitable institutions. Nonetheless there is no definitive pattern between these two factors among the individual states. (p. 30)

Profitability or asset utilization ratios collectively reflect a mixed message for end of the 1990s and provide a basis for uncertainty for looking toward the future. Although giving little credence to those projecting doom and gloom for the banking industry because of geographic expansion, the generally poor profitability performance of the nation's banks as a group must be viewed as discouraging. (p. 30)

Table Two

Measures of Profitability

\begin{tabular}{|c|c|c|c|c|}
\hline Year & $\begin{array}{c}\text { Return } \\
\text { On Assets }\end{array}$ & $\begin{array}{c}\text { Return } \\
\text { On Equity }\end{array}$ & $\begin{array}{c}\text { Percent of } \\
\text { Unprofitable } \\
\text { Institutions }\end{array}$ & $\begin{array}{c}\text { Percent of } \\
\text { Institutions With } \\
\text { Earnings Gains }\end{array}$ \\
\hline 2000 & 1.18 & 13.99 & 7.34 & 67.31 \\
\hline 2001 & 1.16 & 13.15 & 8.13 & 56.27 \\
\hline 2001 & 1.33 & 14.46 & 6.64 & 72.64 \\
\hline 2003 & 1.40 & 15.31 & 6.01 & 59.20 \\
\hline 2004 & 1.30 & 13.72 & 5.87 & 64.83 \\
\hline 2005 & 1.33 & 13.26 & 6.31 & 66.01 \\
\hline Percent Change & 12.71 & -5.22 & -14.03 & -1.93 \\
\hline
\end{tabular}

Source: FDIC, Statistics on Banking

\section{CONSOLIDATION AND PROFITABILITY IN THE U.S. BANKING INDUSTRY SINCE RIEGLE-NEAL: 1999-2004}

Table Two presents data from the FDIC on these four measures of profitability for the 2000-2005 to examine the period after Riegle-Neal became fully effective.

\section{Return on Assets}

For the U.S. banking industry as a whole ROA increased from 1.18 in 2000 to 1.40 in 2003, after which it decreased again to 1.33 in 2005. For the period 2000 to 2005 therefore ROA in the U.S. banking industry increased by $12.71 \%$. Compared to the period 1996-1999 when the immediate impact of Riegle-Neal saw an increase in ROA of $10.08 \%$, the subsequent period since Riegle-Neal has seen an even greater increase in ROA of $12.71 \%$. By this measure then profitability in the U.S. banking industry has increased as consolidation has continued at a somewhat slower pace.

\section{Return on Equity}

As in the case of ROA, the period since Riegle-Neal was one in which ROE increased from 2000 to 2003, from 13.99 to 15.31 , after which it decreased again to 13.26 in 2005 . In this case, however, for the five year period as a whole there was a decrease in ROE of 5.22\%. Unlike the period 1996-1999 when the immediate impact of Riegle-Neal was an increase in ROE of $6.16 \%$, the subsequent period of continuing consolidation since Riegle-Neal has seen a decrease in profitability as measured by ROE.

\section{Percent of Unprofitable Institutions}

During the period 1996-1999 in the immediate aftermath of Riegle-Neal the percent of unprofitable institutions increase 68\%. However, Table Three indicates that in the period since then from 2000 to 2005 the percent of unprofitable institutions decreased by $14.03 \%$. If, as suggested above, one motive for merger activity is 
to replace inefficient management, then this finding of a decrease in the percent of unprofitable institutions is not surprising as more efficient banks buy out less efficient banks returning them to profitability.

\section{Percent of Institutions with Earnings Gains}

From 1996 to 1999 the percent of institutions with earnings gains decreased by $10.82 \%$ nationally. In the subsequent period from 2000 to 2005 the percent of institutions with earnings gains continued to decrease, but only by $1.93 \%$. The percent of unprofitable institutions and the percent of institutions with earnings gains together indicate that in the period of continuing consolidation since Riegle-Neal, a larger percent of U.S. banks are profitable, but the percent whose profitability is increasing is smaller.

\section{CONCLUSION}

This paper has extended previous research which studied the initial impact of the Riegle-Neal Act on consolidation and profitability in the U.S. banking industry by examining the period of time since this deregulation became fully effective to see if the immediate effects set in motion by the passage of the act have continued or moderated.

The data on the number of banking institutions indicate that the number of institutions continues to decrease. However, the rate at which the number of banks is decreasing has slowed since Riegle-Neal became fully effective.

The information on profitability presented here indicates that profitability as measured by ROA has increased, but measured by ROE it has decreased slightly. The percent of U.S. banks which are unprofitable has decreased in the more recent period compared to the increase immediately after Riegle-Neal. The percent of institutions for which earnings are increasing has seen a decline, but to a significantly smaller extent than the earlier period.

\section{AUTHOR INFORMATION}

Joseph N. Heiney received his Ph.D. in Economics from the University of Chicago. He is currently Professor of Economics at Elmhurst College in Elmhurst, Illinois. Previously he served as the Director of the Center for Business and Economics and Coleman Foundation Distinguished Chair at Elmhurst College. His recent research has been concerned with the continuing consolidation in the U.S. banking industry and its effects on asset size distribution, profitability, employment, and compensation.

\section{REFERENCES}

1. Calem, Paul S. "The Impact of Geographic Deregulation on Small Banks," Business Review, (Federal Reserve Bank of Philadelphia), (November - December, 1994), pp. 17 - 31.

2. Calomiris, Charles W. and Jason Karceski. Is the Bank Merger Wave of the 1990's Efficient? Washington, D.C.: The AEI Press, 1998.

3. Carlino, Gerald A. and Keith Sill. "Regional Income Fluctuations: Common Trends and Common Cycles," Federal Reserve Bank of Philadelphia, Working Paper No. 00-8, August, 2000.

4. $\quad$ Economides, Nicholas, R. Glen Hubbard, and Darius Palia. "The Political Economy of Branching Restrictions and Deposit Insurance: A Model of Monopolistic Competition among Small and Large Banks," The Journal of Law and Economics, XXXIX N. 2 (October, 1996), pp. 667-704.

5. $\quad$ FDIC, Statistics on Banking, Historical Statistics on Banking, FDIC web site.

6. Jayaratne, Jith and Philip E. Strahan. "Entry Restrictions, Industry Evolution, and Dynamic Efficiency: Evidence From Commercial Banking." Journal of Law and Economics, XLI (April, 1998), pp. 239 - 273.

7. Matasar, Ann B. and Joseph N. Heiney. The Impact of Geographic Deregulation on the American Banking Industry. Westport, Conn.: Quorum Books, 2002.

8. $\quad$ Rose, Peter. Banking Across State Lines: Public and Private Consequences. Westport, Conn.: Quorum Books, 1997. 
9. Sherwood-Call, Carolyn. "Assessing Regional Economic Stability: A Portfolio Approach," Economic Review, Federal Reserve Bank of San Francisco, Winter, 1990, pp. 17-26.

10. Smoluk, H. J., Bruce Andrews, and John Voyer. "A Methodology for Analyzing the Effects of Geographic Diversification for Financial Institutions," American Business Review, XXI N. 1 (January, 2003), pp. 47-55.

\section{NOTES}

